\title{
Joseph Ratzinger's Philosophical Theology of the Person
}

Joseph Ratzinger's scholarly reflections and ideas convey a philosophical theology of the person that points to relational complementarity. In this article, the author uses the image of a house in order to present Ratzinger's philosophical theology of the human person. The first part of this article examines the foundations of Ratzinger's theology and points out how different philosophers have influenced his understanding of biblical anthropology. The second part presents the architectural supports of Ratzinger's theology, which are the parallels that Ratzinger draws between the body and soul as well as God's transcendence and man. The third section discusses the ceiling, meaning the beams (principles) of Ratzinger's theology: the intellect, love, truth, beauty, and hope. Ratzinger's approach to philosophical theology is both original and creative because he argues that, based on his dialogical understanding of the human person, the individual must transcend himself and because he demonstrates that relationship and dialogue are as primordial a form of being as substance. The essence of Ratzinger's theology of the person is a biblical understanding of the human person that highlights man's unique dialogical relationship to God.

Key words: Joseph Ratzinger, Benedict XVI, theology of the person, personalism, man.

Joseph Ratzinger refers to the personalism and existentialism of the beginning of the 20th century in order to arrive at an understanding of the human person. Basing his reflections on the assumptions of philosophical theories that understand the person as a finite being (das Dasein), Ratzinger's uses divine revelation and, thus, God Himself 
(das Sein Gottes) as the starting point of his theology. According to Ratzinger, this personal approach leads to a concept of man that is based in theology and has its origins in the doctrine of the Trinity and the two natures of Jesus Christ: God and Man. ${ }^{1}$ Because of man's relationship with God, the human person, who is made in the image and likeness of Christ and the Trinity, has a face: he is not just a number, but rather, firmly rooted in love and truth. This Christian concept brings unity and diversity together in man. In Christ, truth and love, reason and relationship are incarnated through love. Christ is the perfect image of God; He is formed as the perfect model for the human person who is created in the "image and likeness" of God.

In his autobiography Milestones, Joseph Ratzinger wrote: "This encounter with personalism [in the thought of Martin Buber] was for me a spiritual experience that left an essential mark, especially since I spontaneously associated such personalism with the thought of St. Augustine, who in his Confessions had struck me with the power of all of his human passion and depth." 2 Through this statement, Ratzinger reveals his philosophical affinity for personalism, upon which he develops his deep theological anthropology.

In Ratzinger's theology, the concept of the human person takes

Theology of Pope Benedict XVI

precedence. What, therefore, does it mean to be human and what hermeneutic key is necessary to understand the human person in a complementary way? In order to expound on this topic, I will use the image of a house. In the first part, I will discuss the foundations; in the second part, I will refer to the supporting beams; and in the third part, I will discuss the ceiling of the house of Ratzinger's hermeneutics of the human person in order to focus on an eternal perspective.

\section{The Foundations of Ratzinger's Hermeneutics of the Human Person}

In his interpretation of the truth about the human person, Ratzinger upholds that it is necessary to use a philosophical and theological hermeneutic in order to arrive at an interpretation of the truth about man. God (and not man himself) is the true hermeneutic. In this instance, man as a person is the suitable instrument of understanding and explication of all signs (words, names, languages) that God, as the highest Person, directs toward man in historical revelation. Such

$1 \quad$ P. Blanco, The Theology of Joseph Ratzinger: Nuclear Ideas, [in:] Theology Today 68 (2011) 2, 153. (153-173)

2 J. Ratzinger, Moje życie, Częstochowa 1998, pg. 50. 
a hermeneutic deals with "the signs of religious faith, their meaning, their significance, their determinants, their objectivity, how they are revealed, and how they relate to life."3 Therefore, when speaking about hermeneutics, it is necessary to determine the principles behind it. ${ }^{4}$

Insofar as interpretations change over time, hermeneutics is a problem in itself. For example, hermeneutics as an exegetical theory arose during the time of Philo. In ancient Christianity, different schools of biblical exegesis (Alexander, Antioch) existed. Over time, however, and particularly during the Middle Ages, the Bible was commonly interpreted in four ways: literally, allegorically, morally, and anagogically. Later, during the $20^{\text {th }}$ century, hermeneutics was understood not only as a method of understanding, but also the art of understanding. Martin Heidegger (1889-1976), Hans-Georg Gadamer (1900-2002), and Paul Ricoeur (1913-2005) were the main proponents of the latter. While the former approach acknowledged the reality of being and the historicity of events, the latter concept focused primarily on analyzing understanding and striving to determine the relationship between words used to describe a given reality. Within hermeneutics, theology cut itself off from its roots and devolved into the philosophy of subjectivity. ${ }^{5}$

In his interpretation of the person, Ratzinger demonstrates a balanced approach that is driven by Divine Revelation. This approach does not emphasize the conflict between truth known by reason and truth revealed by God, but rather preserves the proper hierarchy that subordinates human reason and knowledge to God's infinite intelligence. Such a hermeneutic strives to synthesize faith and knowledge according to St. Augustine's maxim: credo ut intelligam. As a theory of interpretation, Ratzinger's hermeneutics helps to preserve the proper balance between God, His self-revelation in the world, His manifestation in Jesus Christ, existential fulfillment, the presence of these truths in the Bible, along with man's experience and his ability to penetrate

3 C. S. Bartnik, Hermeneutyka personalistyczna, Lublin 1994, pg. 17.

4 John Paul II's christocentric biblical hermeneutics is an excellent example of this. His hermeneutics followed three main principles: 1) an incarnational understanding of God, 2) the Bible's focus on Christ, and 3) kerygmatic implications, meaning "the kerygmatic message of the [biblical] text should be an encounter with Christ." Por. J. Kudasiewicz, Chrystocentryczna hermeneutyka biblijna Jana Pawta II, [in:] W. Chrostowski (ed.), Joannes Paulus II - in memoriam. Księga Pamiatkowa Stowarzyszenia Biblistów Polskich ku czci ojca świętego Jana Pawta II, Warsaw 2006, 209. (207-224)

5 A. Proniewski, Insegnamento dei filosofi e dei teologi, [in:] A. Proniewski, Ermeneutica teologica di Joseph Ratzinger, Lugano 2014, 32-33 (31-34) 
and assimilate this content through reason and faith, which itself can be distinguished further as fides qua and fides quae. ${ }^{6}$

Ratzinger orients philosophy of the person toward theology. He also upholds that it is necessary to interpret the Bible ontologically; for, it is the Word of God, whose power was revealed in the Son of God, Jesus Christ, who unveiled the one and complete truth about man in the Holy Spirit. A philosophy of the person that does not take into consideration a theological perspective provides only a partial understanding of the person. Ratzinger demonstrates that philosophical anthropology and theological anthropology as well as metaphysics and history must remain in respective dialogue with each other. For this reason, a Trinitarian theology of the person and of the community, which unfolds in the person and the works of Jesus Christ and is made tangible in man's relationship to the archetype of the Trinitarian community, serves as the starting and access point for Ratzinger's hermeneutics on the human person.

During Ratzinger's intellectual formation, studies on Theodor Steinbüchel's (1888-1949) works on the philosophical assumptions of theology steered Ratzinger toward the relational personalism that Ferdinand Ebner (1882-1931) and particularly Martin Buber (1878-1965)

Theology of Pope Benedict XVI

promoted. ${ }^{7}$ These studies were rooted in the philosophical principles contained in St. Augustine (354-430) and John Henry Newman's (18011890) thought. On the centennial anniversary of John Henry Newman's death, Cardinal Joseph Ratzinger recalled:

In January 1946, when I began my study of theology in the Seminary in Freising [...] an older student was assigned as prefect to our group, who had begun to work on a dissertation on Newman's theology of conscience [...]. Soon we were bonded by a personal friendship, wholly centred on the great problems of philosophy and theology. Of course Newman was always present. Alfred Lapple - the above-mentioned prefect named-published his dissertation in 1952 with the title: Der Einzelne in der Kirche (The Individual in the Church). [...] For us at that time, Newman's teaching on conscience became an important foundation for theological personalism, which was drawing us all in its sway. Our image of the human being as well as our image of the Church was permeated by this point of departure. [...] Precisely because Newman interpreted the existence of the human being from conscience, that is,

\footnotetext{
$6 \quad$ A.Proniewski, Introduzione,[in:]A.Proniewski,Ermeneutica teologica di Joseph Ratzinger, Lugano 2014, 11.(11-20). Por. E. Ozorowski, Fides qua fides quae, [in:] Rocznik Teologii Katolickiej 8 (2009) pg. 33-41.

7 U. Casale (ed.), Fede, ragione, verità e amore. La teologia di Joseph Ratzinger, Torino 2009, pg. 11.
} 
from the relationship between God and the soul, was it clear that this personalism is not individualism. ${ }^{8}$

This statement reveals that Ratzinger uses the transcendental philosophical method of phenomenology in his interpretation of the human person.

Ratzinger's concept of the human person arises from his initial philosophical and theological formation, which was influenced by St. Augustine's writings, Karl Jaspers' (1883-1969) existentialism, Martin Buber's philosophy of dialogue, as well as Romano Guardini's (18851968) philosophy of religion. ${ }^{9}$ In essence, Ratzinger is a proponent of the personalism and existentialism of the beginning of the $20^{\text {th }}$ century. He founds his concept of the person not only on philosophical and linguistic arguments based on reason, but also-and even more so-on an ontic, structural, theological Trinitarian principle.

\section{The Pillars of Ratzinger's Hermeneutics of the Human Person}

For Ratzinger, the essence of the human person can be found in his different relationships. These relationships, which play out in man's dialogue with God and the world, have an inwardly personal character as well as an exterior character. According to Ratzinger, an understanding of man in his personal and bodily-spiritual existence is indispensible in order to arrive at a complete and definitive hermeneutic of the human person. For this reason, Ratzinger upholds that it is necessary interpret man's corporal-spiritual make-up along with the meaning and purpose of man's existence, which can be found in God's transcendence. ${ }^{10}$

For Ratzinger, an understanding of the human soul, which includes the dialogicity of the human being, is key. By using the Aristotelian and Platonic term psyche (soul), Ratzinger delves to the depth of philosophical anthropology. He includes the spiritual nature of the soul in his analyses and, in so doing, follows in the footsteps of philosophers who have considered this subject throughout the ages, especially

8 J. Ratzinger, Discorso introduttivo alla III giornata del Simposio di Newman, [in:] Euntes Docete (1990), pg. 432-433.

$9 \quad$ Por. M. Jaworski, Eidos chrześcijaństwa w nawiąaniu do poglądów Romano Guardiniego, [in:] Logos i Ethos 2(2013), pg. 43-44.

10 J. Ratzinger, Tymczasowe sprawozdanie na temat dyskusji (1990). Postowie do 6. wydania, [in:] J. Ratzinger, Opera omnia. Zmartwychwstanie i życie wieczne, vol. X, Lublin 2014, 223. (223-240) 
Thomas Aquinas who wrote extensively on this topic. "In response to the question of the soul, Thomas and Aristotle respond using the formula anima forma corporis - the soul is the form of the body." 11 Aquinas, however, had a deeper understand of the soul than Aristotle because he perceived that the soul is simultaneously the personal element and the form of the material body. In this respect, Ratzinger emphasizes Thomas Aquinas' teaching that the rational spiritual substance is the substantial form of the material body, which "should be considered an historical moment." "Here we come to a stupendous statement: within man the soul is united with the body so closely that it is possible to use the word 'form' and everything that it signifies in reference to [the body]. Conversely, the form of the human body is such that it is the soul and, therefore, make man a person." ${ }^{13}$ The separation of body and soul is against man's nature and diminishes his likeness to the Creator. Ratzinger follows Thomas Aquinas' logic when he states: "The soul belongs to the body as its form, while the spirit, which is the form of the body, makes man a person and opens him to immortality."14 On the one hand, the anima (soul) enters into the material and bodily world, while, on the other hand, surpasses and transcends this world and strives for union with God Himself. "In man's turning to God, 'all

Theology of Pope Benedict XVI the tributaries of finite being in all its variety of level and value, return to their Source.' Man is conceived as a being 'capable of the knowledge and love of God and called thereto." "15

Ratzinger adds: "A being is the more itself the more it is open, the more it is in relationship. And that in turn will lead us to realize that it is the man who makes himself open to all being, in its wholeness and in its Ground, and becomes thereby a 'self,' who is truly a person. Such openness is not a product of human achievement. It is given to man, and man depends for it on Another. But it is given to man to be his very own possession." "16 According to this concept of man, it is clear that, through the resurrection, both the soul and body of man will participate in the eternal glory of heaven because all of man-the entire human person-will be redeemed. This is what Thomas Aquinas had

11 J. Ratzinger, Nieśmiertelność duszy i zmartwychwstanie umartych, [in:] J. Ratzinger, Opera omnia. Zmartwychwstanie i życie wieczne, vol. X, Lublin 2014, pg. 150.

12 Ibidem.

13 Ibidem, pg. 150-151.

$14 \quad$ Ibidem, pg. 151.

$15 \quad$ Ibidem, pg. 154.

$16 \quad$ Ibidem, pg. 155. 
in mind when he stated that immortality is proper to man by his very nature, which God bestowed on him in the act of creation. ${ }^{17}$

The human person embodies a telling paradox-namely, he appears in his body and simultaneously transcends his own physicality because he exists for all eternity. A spiritual soul forms human corporeality and ensures its spiritual existence. Ratzinger writes, "immortality is not within man's capacity; rather, it depends on his special relationship with that which is eternal and that which eternity makes sensible. Truth and love last and can give and fulfill life. Man can live eternally because he capable of entering into a relationship with the one who imparts eternity to him. We call the soul that which supports this relationship in man. The soul is nothing other than man's ability to develop a relationship with Truth, with eternal Love. Reality can be properly ordered in this way: Truth, who is Love, meaning God, gives man eternity. Because matter is integrated into the human spirit- the human soul, matter attains its fulfillment in the soul in the Resurrection." 18 Although the bodily aspect of human existence is so obvious that man is often drawn only to the material dimension of life, his being is not limited to the bodily dimension.

In his anthropological studies, Ratzinger refers to Teilhard de Chardin (1881-1955), who understood man as a finite being, on the one hand, and yet, whose entire existence is oriented toward the infinite, on the other. "19an was not simply thrown into the world in the game of evolution. Each person is a being that is wanted by God. Each person is a thought of God." ${ }^{20}$ Existentially, man is very complex, and it is very difficult to describe him by using simple philosophical or theological concepts. Even the traditional formulation that speaks of man as being made up of body and soul does not exhaust the reality of his richness. Every person is created as a biological being. At the same time, however, he is something more than a product of his genes and DNA; he is a being that comes directly from God." ${ }^{21}$ According to Ratzinger, in his uniqueness, man is a bridge between the material and spiritual world,

\footnotetext{
$17 \quad$ Ibidem.

18 J. Ratzinger, Aneks. Pomiędzy śmiercia a zmartwychwstaniem, [in:] J. Ratzinger, Opera omnia. Zmartwychwstanie i życie wieczne, vol. X, Lublin 2014, pg. 256.

19 See J.Ratzinger, Drogi chrystologii, in: J. Ratzinger, Opera omnia. Wprowadzenie do chrześcijaństwa, vol. IV, Lublin 2017, pg. 194.

20 J. Ratzinger, O Bogu, [in:] J. Ratzinger, Opera omnia. W rozmowie $z$ czasem, vol. XIII/2, Lublin 2017, pg. 476.

21

Ibidem, pg. 477.
} 
since "spirit and matter interpenetrate each other"22 in him. In man, "matter is elevated to the realm of the soul. As a result of this fusion, the soul and matter are compatible. Matter is no longer a separate sphere into which the soul cannot fully enter." ${ }^{23}$ These spiritual and material dimensions are interconnected in man; therefore, the unity of creation is made manifest in him. "Man's unique role stems from here; he is the mainstay of the union of creation because he embodies the spirit within himself and, by doing so, simultaneously elevates matter toward God." ${ }^{24}$ It is for this reason that Ratzinger emphasizes that "Man is most himself when he is whole in humanity, in history, in the cosmos-when his 'body and soul' are assimilated." 25

According to Ratzinger, studies on the historicity of man are important in an analysis of the human spirit. Humanity and historicity, the spirit and history, are inextricably connected. The human spirit creates history, which, in turn, conditions human existence. "The soul is expressed in its ability to transcend time. Before all else, the soul is the memory that creates a bond that transcends the boundaries of time." 26 Basically, the spirit overcomes limits. The soul also demonstrates that it is, in fact, a spirit through its ability to remember (memory) and create tradition. History, however, enables man to be human insofar as

Theology of Pope Benedict XVI it allows him to form relationships with other people that transcend time. These relationships are necessary for the human spirit to express itself. The ability to stop and preserve the past is equal to the ability to anticipate and even create the future in the present. ${ }^{27}$

Joseph Ratzinger notes that "the anthropological issues considered by contemporary Christian theology, particularly questions about human nature and man's fate after death, as well as traditional views that have been called into question, including the concept of the soul, have led theologians to try to develop a new understanding of corporeality. He perceives that the strength of new anthropological solutions can be found in the convergence of the biblical concept of man, which sees man as absolutely inseparable [from his soul], with modern anthropology, which arises from the natural sciences, asserts

22 J. Ratzinger, Znaczenie niedzieli dla modlitwy i życia chrześcijanina, [in:]

J. Ratzinger, Opera omnia. Teologia liturgii, vol. XI, Lublin 2012, 226.

$23 \quad$ J. Ratzinger, O Bogu, pg. 487.

24 Ibidem.

25 J. Ratzinger, Drogi chrystologii, pg. 198.

26 J. Ratzinger, Antropologiczne uzasadnienie pojęcia tradycji, [in:] J. Ratzinger, Opera omnia. Wiara w Piśmie i Tradycji, vol. IX/1, Lublin 2018, pg. 425.. 
that man exists only in the body and, therefore, precludes the existence of a soul that can be separated from man's body. However, [according to Ratzinger], the fact that some theologians concede to the logic of contemporary thought and, consequently, do not recognize that man has an immortal soul, still does not resolve the tension that exists between the biblical image of man and the image upheld by the natural sciences, because the biblical writer and modern man have completely mindsets. Therefore, within anthropological analyses, scholars must reject the temptation to fall into 'flat-out biblicism,' which is also unable to resolve the fundamental contradictions that are inherent in a theological understanding of man." 28

The Bible sets man apart from the rest of creation and points out that his activity expresses his transcendence. Man as a corporeal and spiritual being is connected directly to God through the creative act. His soul, which is alive and life itself, differentiates him from all of the other animals. "The soul merges completely with his biological being and imparts a new and broader dimension to his life." ${ }^{29}$ The biblical description of creation speaks of man's duality—his belonging to the cosmos and his relationship with God. "Heaven and earth converge on each other in man." ${ }^{30}$ Because of the divine breath that breathes life into man, man is able to cross over from the material world to God. The divine breath, which is evident in the fact that man is ordered to God in a particular way, makes every person unique and unrepeatable. "Man is the creature in whom the soul and matter unite into one whole. If we downplay the word 'soul,' then we unavoidably fall into materialism, where the body is no longer elevated, but rather robbed of own dignity." 31 Although man exists within temporal and spatial reality through his material body, he is able to transcend and surpass this reality because of his soul. "The anima, as we have seen, belongs completely to the material world, yet also goes beyond this world in

$28 \quad$ Por. J. Ratzinger, Nieśmiertelność duszy i zmartwychwstanie umartych, [in:] J. Ratzinger, Opera omnia. Zmartwychwstanie i życie wieczne, vol. X, Lublin 2014, pg. 117.

29 J. Ratzinger, O życiu, [in:] J. Ratzinger, Opera omnia. W rozmowie $z$ czasem, vol. XIII/2, Lublin 2017, pg. 622.

30 J.Ratzinger,Stworzenie człowieka, [in:] J. Ratzinger, Na początku Bóg stworzyt..., Cracow 2006, pg. 51.

$31 \quad$ J. Ratzinger, Moim szczęściem jest być w Twojej bliskości. O chrześcijańskiej wierze $w$ życie wieczne, [in:] J. Ratzinger, Opera omnia. Zmartwychwstanie i życie wieczne, vol. X, Lublin 2014, pg. 437-438. 
going beyond itself. It is in that movement that the material world, indeed, comes into its own, by stretching forth towards God in man." 32

Karl Rahner (1904-1984) considered man a unique being without any equal in the world. He called man a "spirit in the world" and completely open to being since he always surpasses that which he knows and everything that he does. As a spirit in the world, man is an embodied spirit. Consequently, his spiritual nature orients him toward history; whenever he comes to know something, he does so through his senses, turning toward that which is historical. "In radically experiencing his own finiteness," man "transcends this finitude and experiences himself [...] as a soul." " Moreover, "man is a soul that experiences himself as a soul. He does not, however, experience himself exclusively as a soul." 35 Rahner considered the origin of the spirit in matter that is evolving and gradually interiorizing itself. Originating from God, the human soul must rise up during the active auto-transcendence of matter. Man-an embodied spirit-is the pinnacle of this evolutionary process.

Studies on what makes man a man-on the essence of humanity—are significant in Joseph Ratzinger's anthropology. According to Ratzinger, only by faith does man enter into the twofold mystery of his own being: of his personal and bodily-spiritual existence.

Theology of Pope Benedict XVI
The most individual element in us - the only thing that belongs to us in the last analysis-is our own 'I,' is at the same time the least individual element of all, for it is precisely our ' $I$ ' that we have neither from ourselves nor for ourselves. The ' $\mathrm{I}$ ' is simultaneously what I have completely and what least of all belongs to me. Thus here again the concept of mere substance (= what stands in itself!) is completely shattered, and it is made apparent how being that truly understands itself truly grasps at the same time that in being itself it does not always belong to itself; that it only comes to itself by moving away from itself and finding its way back as relatedness to its true primordial state. [...] When we speak about God, we realize what man is. ${ }^{36}$

Ratzinger uses two ideas that play an important role in contemporary thought to explain this: first, the essence of the spirit as a being

32 J. Ratzinger, Nieśmiertelność duszy i zmartwychwstanie umartych, pg. 154.

33 Por. A. Proniewski, Il Battesimo in relazione alla natura e alla missione salvifica della Chiesa secondo Karl Rahner, Rome 2000, pg. 55.

34 K.Rahner, Podstawowy wyktadwiary. Wprowadzenie do pojęciachrześcijaństwa, Warsaw 1987, pg. 32.

35 Ibidem.

36 J. Ratzinger, Wiara $w$ Boga Trójjedynego, [in:] J. Ratzinger, Wprowadzenie do chrześcijaństwa. Opera omnia, vol. IV, Lublin 2017, pg. 158. 
outside of itself and a being in relation to others, and, second, a dialogical understanding of personalness in general.

According to Ratzinger, the essence of man's spirit is his ability to go beyond himself, to transcend himself. Matter is closed in on itself, whereas the soul is able to transcend the limits of the body, go beyond itself, and look at itself from the outside. Because of its capacity to transcend, the soul is able to form itself. Because of who man is by his very nature, matter is elevated to the realm of the spirit. ${ }^{37}$ The essence of man is his openness and reference to the whole. Man is more within himself the more that he transcends himself and moves toward the ultimate, toward God.

In order to substantiate his assertion that the transcendence of the human spirit is an indication that the spiritual soul exists, Ratzinger bases his arguments on the scholastic epistemic axiom that St. Thomas Aquinas (1225-1274) formulated based on Aristotle's (384-322 BCE) thought: Nihil est in inlellectu, quod non prius fuerit in sensu (There is nothing in the intellect that was not first in the senses). ${ }^{38}$ Sense knowledge is the precursor for every other kind of knowledge. This fundamental assertion in Thomas Aquinas' epistemology corresponds to the basic anthropological formula that asserts that man is an embodied spirit. However the Angelic Doctor's other expression anima forma corporis (the soul is the form of the body) ${ }^{39}$ connects the soul and body in such a way that they constitute one entity. "Man is the creature in whom the soul and matter meet and are united into one whole." ${ }^{40}$ This implies that, on the one hand, the human spirit essentially exists through the strength of the body and, on the other hand, that human corporeality is essentially an expression of the spirit. Thus, human knowledge inherently involves the activity of the corporal body (sense) and intellectual knowledge (intellect). All human cognition functions in this way-it begins in experience, in what the human person receives through his senses. Therefore, in man the soul exists only as an embodied spirit. ${ }^{41}$

$37 \quad$ J. Ratzinger, O Bogu, pg. 487.

38 See idem, Doświadczenie a wiara, Communio (Pl) 1 (1981) 4, pg. 16.

$39 \quad$ Idem, Doświadczenie a wiara, pg. 17.

$40 \quad$ Idem, Moim szczęściem jest być w Twojej bliskości, [in:] J. Ratzinger. Opera omnia. Zmartwychwstanie i życie wieczne, vol. X, Lublin 2014, pg. 437.

41 See idem, Nieśmiertelność duszy i zmartwychwstanie umartych, pg. 158-159. 


\section{The Ceiling of Ratzinger's Hermeneutics of the Human Person}

Having discussed the foundations and supports of the house of Ratzinger's hermeneutics of the human person, it is necessary to examine the anthropological and ontological principles behind Ratzinger interpretations. According to Ratzinger, the person has a deep inner primordial connection to the intellect, love and truth, beauty and hope. Essentially the intellect, love, truth, beauty, and hope are the five main beams that serve to stabilize the ceiling that culminates his concept of the human person. These "beams" serve to extend man's earthly existence into eternity.

The intellect is an important subject of study and plays in an important role in Ratzinger's writings on the human person. For Ratzinger, the intellect is the place where mystery and rationality meet. Ratzinger mentions that there must be a harmony between faith and the intellect in man. "Faith appeals to our reason because it expresses truth and because reason was created for the truth. In this sense, faith without the reason is not proper Christian faith." ${ }^{2}$ The origins of the Church are clearly rational. Human faith requires understanding and always

Theology of Pope Benedict XVI contains and element of rationality. In the personal act of faith there is this moment and this rational dimension, both of which constitute an irrevocable instance of a personal category.

A truly human act cannot exist without the intellect and faith. Faith enables man to have a broader and better vision of that which the intellect offers to him. ${ }^{43}$ Ratzinger proposes a metaphysical understanding of reason. This does not mean that reason must be pure, mathematical, purely technical, or instrumental. It means, rather, that reason must be universal and open-it should be disposed to art, ethics, religion, and even to the emotions. Thus, reason must be open to its own source: the Logos who is simultaneously a person and love and who gives meaning to all things. An intimate union between logos and agape, the intellect and relationship, truth and love in Christ and the Spirit, who is the foundation of all truth, of a capacity to understand, and the ability to love, proceeds from reason.

In his academic works, Ratzinger constantly emphasizes the indissoluble union between love and truth, both of which make up the phenomenon that is the human person. In order for man to be fully

42 Idem, Prolog: wiara, nadzieja, miłość, [in:] J. Ratzinger, Opera omnia. W rozmowie z czasem, vol. XIII/2, Lublin 2017, pg. 455.

43 See idem, Wprowadzenie, [in:] J. Ratzinger, Opera omnia. Wprowadzenie do chrześcijaństwa, vol. IV, Lublin 2017, pg. 62-66. 
human, love and logos must meet within him. This is one of the first conclusions to which Ratzinger came to when he began to study Augustine, Thomas Aquinas, Bonaventure (1221-1274), and Romano Guardini (1885-1968), and this topic has undoubtedly continued to be a part of Ratzinger's intellectual development.

"God is love" (1 John 4:16). God loves man, and the human person is capable of love because of God's love. "The argument that God is love really begs the question: 'Who loves whom?' The Trinitarian makeup of God, which is self-gift and bears the Son, who gives himself over to the Father through the breath of the Holy Spirit, is the answer to this question." ${ }^{44}$ According to Ratzinger, love is part of the definition of the human person. "God created in man a desire for love, for a relationship with others. God created man primarily to seek love and relationships with others." ${ }^{45}$ Love, tenderness, and personal feelings are not limited only to the purely human realm and cut off from the divine. Not every kind of love, however, has value. Love must grow and become better, greater, and purer. "As the creative love of God, the Logos is the origin of everything." ${ }^{46}$ Through its encounter with the Logos in whom God revealed himself as Love, and through purification, human love becomes more and more like divine love. As a result of this process, the identity of the human person becomes complete. "As the French philosopher Gabriel Marcel once stated, 'Love is the antidote to death.' This love becomes a reality only when it has been promised by one and received by another-when it is embrace by the Love that truly bestows eternity [on the other]." 47

From his very first theological writings it is clear that truth is also one of the topics upon which Ratzinger continually reflects. He bases these reflections on Augustine, Thomas Aquinas, Bonaventure, Henry Newman, and Romano Guardini. ${ }^{48}$ Truth and love are the two complementary principles of the human person. Man needs "love in truth" and "the truth of love," meaning the love of logos in order to attain true freedom. "The essence of love is expressed in the words: 'I want you to exist.' Such love is a creative power that calls into being a dependence

\footnotetext{
$44 \quad$ J. Ratzinger, O Bogu, pg. 494.

$45 \quad$ Ibidem, pg. 502.

$46 \quad$ K. Góźdź, Realność i racjonalność wiary, [in:] K. Góźdź, Logos i mitość. Teologia Josepha Ratzingera/Benedykta XVI, Lublin 2018, pg. 98.

$47 \quad$ J. Ratzinger, O Bogu, pg. 556.

48 Por. A.Proniewski, Inquadramento degli influssifilosofico-teologici, [in:]A.Proniewski, Ermeneutica teologica di Joseph Ratzinger, Lugano 2014, pg. 38-55.
}

\section{Theology \\ of Pope \\ Benedict XVI}


that is transformed into freedom." ${ }^{49}$ This truth makes people free (por. John 8:32). Through falsehood man cuts himself off from the roots of his being. Freedom alone does not liberate man if it is not oriented toward truth. "Man is not a predetermined being created to reflect a specific image. Rather, freedom exists so that every individual can plan his own life and, in his own I, follow the path that suites his being." 50 Negation of the truth leads to totalitarianism, to the "dictatorship of relativism." The relationship that exists between truth and freedom is necessary to understand the human person. Ratzinger arrives at the relationship between truth and freedom through a phenomenological understanding of the conscience, which can deal with difficult but realizable truth: "the freedom of God and the freedom of man encounter each other within the conscience without any antonymity." ${ }^{51}$ Man's ability to know the truth with the help of reason and the conscience (also on a practical level) gives him hope that he will become freer. According to Ratzinger, the truth ensures personal freedom. In this way, he puts forth an entire theory of freedom, at the center of which is the person of Christ as the pinnacle of human existence. Ratzinger's works serve as an eloquent reminder of the theological foundation of truth.

Ratzinger has always been a man who deeply appreciates beauty. Art

Theology of Pope Benedict XVI and beauty are two other points of departure for his reflections, which is due largely in part to his own personal experiences in these areas. His three great predecessors: Augustine, Aquinas, and Bonaventure highly valued the aesthetic dimension of life. For Ratzinger, beauty has never become one of the forgotten transcendentalias; for, from his earliest years, Joseph loved music and art as a means of knowing. As J. Szymik points out, in music and art Ratzinger "is able to confirm this living and constant presence of creative Reason, to exist and develop according to the measure of the Logos and in accordance with the Logos." "52 Reason and beauty complement each other. Ratzinger asserts that "reason itself as it appears in science is unable to be man's complete response to reality and it is unable to express everything that man is capable of, desirous to, and must express. I think that God breathed art into human souls. Art-in addition to science-is the

$49 \quad$ K. Góźdź, Chrystologia Logosu, [in:] K. Góźdź, Logos i miłość. Teologia Josepha Ratzingera/Benedykta XVI, Lublin 2018, pg. 29.

$50 \quad$ J. Ratzinger, O Bogu, pg. 490.

$51 \quad$ J. Szymik, Ocembrować źródło. Sumienie jako anamnesis i conscientia, [in:] idem, Theologia Benedicta, vol. III, Katowice 2015, pg. 327.

52 Idem, Estetyka teologiczna. Strzał piękna, rana miłości, [in:] idem, Theologia Benedicta, vol. I, Katowice 2010, pg. 107. 
highest gift that man can receive from God." ${ }^{53}$ The art that Ratzinger proposes is art that is created with the mind and the heart, with ideas and feelings. In this way, the unity of the human person is enriched in the aesthetic realm.

Ratzinger believes that beauty is truly indispensible for man because it is higher form of knowing that hearkens to man's source, meaning God Himself. For, Christ will be both the greatest personal earthly beauty as well as the One who is "the most handsome of men" (Ps 45:3). This is the beauty of Christ after He has walked the way of the Cross, been crucified, died, and has risen. The search for all beauty finds it culmination in the beauty of Christ who takes even suffering and death on Himself in order to transform them into the glory of the resurrection.

In order to add to his understanding of the human person, Ratzinger examines what happens to man after death. Starting from the concepts of historia salutis, Ratzinger arrives at the ontological dimension of human existence. According to Ratzinger, salvation is also the history and ontology of the human person. The history of salvation plays out in the present; for, it is within the present that each person realizes his relationship with God. In this sense, Ratzinger is also critical of the myth of progress; for, not everything improves just because something has changed: the past is also valuable to the present, which needs to be actualized in every moment of history.

The future must be anchored in the past, in the here and now, andbefore all else-in eternity. It is for this reason that "the Resurrection of the Dead on the day of the Final Judgment will bring forth a new creation that will preserve man's identity as a being comprised of a body and soul. In this regard, St. Thomas Aquinas says that the soul is the force that forms the body - that precisely the soul creates the body for itself. Therefore, identity means that the soul will be granted its formative power anew and will rebuild its identical body from within at the resurrection." ${ }^{54}$ In this way, hope is real. The human person participates in the Person of God and in the Resurrection of His Son. Thus, man is ontologically rooted in eternity and a firm Christological foundation. "[...] Christ is, as it were, the end that has begun, and that

\footnotetext{
53 J. Ratzinger, Wokół osoby, [in:] J. Ratzinger, Opera omnia. W rozmowie z czasem, vol. XIII/1, Lublin 2017, pg. 231.

$54 \quad$ Idem, O Kościele, [in:] J. Ratzinger, Opera omnia. W rozmowie z czasem, vol. XIII/1, Lublin 2017, pg. 740.
} 
the world, while moving away from him, is nonetheless moving toward him again." ${ }^{55}$ Christ and his glorious resurrection are the future.

\section{Conclusion}

Although Joseph Ratzinger refers to ancient and early Christian ideas when developing his concept of the human person, his work on this subject consistently refers to contemporary philosophy and theology. The ideas of twentieth-century thinkers and proponents of personalism such as the philosopher Max Scheler (1874-1928) and the theologians Henri de Lubac (1896-1991), Hans Urs von Balthasar (1905-1988), and Yves Congar (1904-1995) are very evident in Ratzinger's hermeneutics.

The theology of the person that Ratzinger has developed is based on the biblical image of the person, which affirms man's unique and dialogical relationship to God, in which lies the essence of personalism. While the personalistic theology that influences Ratzinger's ideas is obvious, the degree to which philosophy influences his thinking is less obvious. Ratzinger is certainly influenced by contemporary philosophical personalism, but its influence is indirect and evident

Theology of Pope Benedict XVI primarily through his academic works. When developing his concept of man and the human soul, Ratzinger does not refer directly to proponents of personalism such as Martin Buber (1878-1965), Ferdinand Ebner (1882-1931), or Franz Rosenzweig (1886-1929). He does, however, sometimes refer to contemporary dialogical thought, even though his ideas do not completely identify with it. Dialogical philosophical personalism serves only as starting point for Ratzinger's ideas, while Ratzinger, on his part, tries to restore to personalism its primordial depth by using it to work out his concept of the person as well as a dialogical understanding of reality in general.

Ratzinger's philosophical theology of the human person is original and creative because his dialogical understanding of the human person includes man's need to transcend himself and demonstrates that relationship and dialogue are as primordial a form of being as substance.

55 J. Ratzinger, U progu nowej epoki, [in:] J. Ratzinger, Opera omnia. W rozmowie z czasem vol. XIII/1, Lublin 2017, pg. 411. 


\section{FILOZOFICZNA TEOLOGIA OSOBY W UJĘCIU JOSEPHA RATZINGERA}

Filozoficzna teologia osoby pokazuje na komplementarność relacji występującą w refleksji naukowej w ujęciu J. Ratzingera. Autor artykułu w przedłożeniu tematu posłużył się obrazem domu. W pierwszej odsłonie odwołał się do fundamentów, w których pokazuje na wpływ filozofów na rozumienie biblijnej antropologii przez Ratzingera, w drugiej do filarów, którymi uczynił paralelizm ciało-dusza i transcendencję Boga i człowieka, w trzeciej do sklepienia, którego zasadniczymi belkami są: intelekt, miłość, prawda, piękno i nadzieja. Filozoficzna teologia osoby Ratzingera ma cechy oryginalności i twórczego ujęcia, gdyż w dialogicznym rozumieniu osoby ludzkiej zawiera on konieczność przekroczenia jednostki, a relacja i dialog okazują się równie pierwotną formą bytu, co substancja. Teologię osoby, którą uprawia, opiera na biblijnym obrazie człowieka, ukazującym jego wyjątkową, dialogiczną relację do Boga i w tym zawiera się jej istota.

Słowa kluczowe: Joseph Ratzinger, Benedykt XVI, teologia osoby, personalizm, człowiek.

\section{Bibliography:}

1. Bartnik Cz. S., Hermeneutyka personalistyczna, Lublin 1994.

Theology of Pope Benedict XVI

2. Blanco P., The Theology of Joseph Ratzinger, Nuclear Ideas, [in:] Theology Today 68 (2011) 2.

3. Casale U., ed. Fede, ragione, verità e amore. La teologia di Joseph Ratzinger, Torino 2009.

4. Góźdź K., Chrystologia Logosu, [in:] K. Góźdź, Logos i miłość. Teologia Josepha Ratzingera/Benedykta XVI, Lublin 2018.

5. Góźdź K., Realność i racjonalność wiary, [in:] K. Góźdź, Logos i mitość. Teologia Josepha Ratzingera/Benedykta XVI, Lublin 2018.

6. Jaworski M., Eidos chrześcijaństwa w nawiązaniu do poglądów Romano Guardiniego, [in:] Logos i Ethos 2(2013).

7. Kudasiewicz J., Chrystocentryczna hermeneutyka biblijna Jana Pawta II, [in:] W. Chrostowski (ed.), Joannes Paulus II - in memoriam. Ksiegga Pamiatkowa Stowarzyszenia Biblistów Polskich ku czci Ojca Świętego Jana Pawta II, Warsaw 2006, 209.

8. Ozorowski E., Fides qua fides quae, „Rocznik Teologii Katolickiej” 8 (2009).

9. Proniewski A., Il Battesimo in relazione alla natura e alla missione salvifica della Chiesa secondo Karl Rahner, Rome 2000.

10. Proniewski, A. Inquadramento degli influssi filosofico-teologici, [in:] A. Proniewski, Ermeneutica teologica di Joseph Ratzinger, Lugano 2014, 35-55.

11. Proniewski A., Insegnamento dei filosofi e dei teologi, [in:] A. Proniewski, Ermeneutica teologica di Joseph Ratzinger, Lugano 2014. 
12. Proniewski A., Introduzione, [in:] A. Proniewski, Ermeneutica teologica di Joseph Ratzinger, Lugano 2014.

13. Rahner K., Podstawowy wykład wiary. Wprowadzenie do pojęcia chrześcijaństwa, Warsaw 1987.

14. Ratzinger J., Aneks. Pomiędzy śmiercia a zmartwychwstaniem, [in:] J. Ratzinger, Opera omnia. Zmartwychwstanie i życie wieczne, Vol. X, Lublin 2014.

15. Ratzinger J., Antropologiczne uzasadnienie pojęcia tradycji, [in:] J. Ratzinger, Opera omnia. Wiara w Piśmie i Tradycji, Vol. IX/1, Lublin2018.

16. Ratzinger J., Discorso introduttivo alla III giornata del Simposio di Newman, [in:] Euntes Docete (1990).

17. Ratzinger J., Doświadczenie a wiara, Communio (Pl) 1 (1981) 4.

18. Ratzinger J., Drogi chrystologii, [in:] J. Ratzinger, Opera omnia. Wprowadzenie do chrześcijaństwa, Vol. IV, Lublin 2017.

19. Ratzinger J., Moim szczęściem jest być w Twojej bliskości. O chrześcijańskiej wierze w życie wieczne, [in:] J. Ratzinger, Opera omnia. Zmartwychwstanie i życie wieczne, Vol. X, Lublin 2014.

20. Ratzinger J., Moje życie, Częstochowa 1998.

21. Ratzinger J., Nieśmiertelność duszy i zmartwychwstanie umartych, [in:] J. Ratzinger, Opera omnia. Zmartwychwstanie i życie wieczne, Vol. X, Lublin 2014.

22. Ratzinger J., O Bogu, [in:] J. Ratzinger, Opera omnia. W rozmowie z czasem, Vol. XIII/2, Lublin 2017.

Theology of Pope Benedict XVI

23. Ratzinger J., O Kościele, [in:] J. Ratzinger, Opera omnia. W rozmowie z czasem, Vol. XIII/1, Lublin 2017.

24. Ratzinger J., O $\dot{z} y c i u$, [in:] J. Ratzinger, Opera omnia. W rozmowie z czasem, Vol. XIII/2, Lublin 2017.

25. Ratzinger J., Prolog: wiara, nadzieja, miłość, [in:] J. Ratzinger, Opera omnia. W rozmowie z czasem, Vol. XIII/2, Lublin 2017.

26. Ratzinger J., Stworzenie człowieka, [in:] J. Ratzinger, Na początku Bóg stworzyt..., Cracow 2006.

27. Ratzinger J., Tymczasowe sprawozdanie na temat dyskusji (1990). Postowie do 6. wydania, [in:] J. Ratzinger, Opera omnia. Zmartwychwstanie i życie wieczne, Vol. X, Lublin 2014.

28. Ratzinger J., U progu nowej epoki, [in:] J. Ratzinger, Opera omnia. W rozmowie z czasem, Vol. XIII/1, Lublin 2017.

29. Ratzinger J., Wiara w Boga Trójjedynego, [in:] J. Ratzinger, Wprowadzenie do chrześcijaństwa. Opera omnia, Vol. IV, Lublin 2017.

30. Ratzinger J., Wokót osoby, [in:] J. Ratzinger, Opera omnia. W rozmowie z czasem, Vol. XIII/1, Lublin 2017.

31. Ratzinger J., Wprowadzenie, [in:] J. Ratzinger, Opera omnia. Wprowadzenie do chrześcijaństwa, Vol. IV, Lublin 2017.

32. Ratzinger J., Znaczenie niedzieli dla modlitwy i życia chrześcijanina, [in:] J. Ratzinger, Opera omnia. Teologia liturgii, Vol. XI, Lublin 2012.

33. Szymik J., Estetyka teologiczna. Strzat piękna, rana mitości, [in:] J. Szymik, Theologia Benedicta, Vol. I, Katowice 2010.

34. Szymik J., Ocembrować źródto. Sumienie jako anamnesis i conscientia, [in:] J. Szymik, Theologia Benedicta, Vol. III, Katowice 2015. 